\title{
THE BLOOD IS RICH IN DIFFERENT TYPES OF MESODERM DERIVED STEM AND PROGENITOR CELLS
}

\author{
KOVAČEVIĆ FILIPOVIĆ Milica* \\ Faculty of Veterinary Medicine, University of Belgrade, Serbia
}

(Received 26 May; Accepted 3 June 2014)

\begin{abstract}
The blood and bone marrow have been thoroughly investiagated for more than a century, but we are still gaining surprising new informations. Blood transports different mature cells such as erythrocytes, platelets and granulocytes, but curiously, the blood is also transporting a number of non-differentiated cells of various mesodermal lineages: hematopoietic and mesenchymal stem and progenitor cells, endothelial progenitor cells and very small embryonal like cells are some of the most impressive examples. In adults the bone marrow is the source of practiclly all cells that could be found in the blood. Stem and progenitor cells egress from the bone marrow and home to the bone marrow or various tissues in a highly regulated manner. The fact that the hematopoetic stem and progenitor cells traffic through the blood and repopulate the bone marrow niche is largely explored in stem cell therapy in human medicine. In this review we will briefly describe the main characteristics of stem and progenitor cells, the mechanisms of their mobilization from the bone marrow and homing to target tissues. Also, the history and importance of the fact that different stem, progenitor and precursor cells could be isolated from the blood circulation will be discussed in the light of informations concerning their use in human and veterinary medicine.
\end{abstract}

Key words: peripheral blood, stem cells, progenitor cells, veterinary medicine

\section{INTRODUCTION}

Commonly identified blood cells are differentiated cells of myeloid and lymphoid lineages, produced in the bone marrow $(\mathrm{BM})$ and released to perform their functions in the circulation or after migration to different tissues. Apart from differentiated cells the bone marrow also releases into the blood several mesoderm derived nondifferentiated cell types. Namely, in human and animal cord and peripheral blood the presence of multipotent hematopoitic stem cells (HSC) and multiple types of

* Corresponding author: e-mail: milica@vet.bg.ac.rs 
commited hematopoietic progenitor cells (HPC) including osteoclast progenitor or precursor cells (OPC) has been demonstrated. Endothelial progenitor cells (EPC) are a distinict population of mesoderm derived cells that have the ability to differentiate to endothelial cells. Although being considered as sessile, mesenchymal stromal/stem cells (MSC) and osteoprogenitor cells were also found in the blood. More curiosly, cells of hematopoietic lineage, disguised in a mesenchymal mantle, called fibrocytes, are also present in the blood. The function of the listed stem and progenitor cells is versatile, but they posses similar mechanisms to enter and exit the blood. In this review we will briefly describe the main characteristics of stem and progenitor cells, mechanisms of their mobilization from the bone marrow and homing to target tissues. Also, the history and importance of the fact that they could be isolated from the blood circulation will be discussed in the light of informations concerning their use in human and veterinary medicine.

\section{Stem and progenitor cell characteristics}

The classical model of hierarchically organized adult cell populations implies the existence of: 1) a small number of quiescent non-differentiated multipotent stem cells; 2) a broader range of committed progenitor cells that extensively proliferate and differentiate on tissue demand and 3) a large number of mature cells. True stem cells are capable of self-renewal. They perform asymmetrical divisions producing one identical daughter cell that maintains their own population and one cell that undergoes differentiation and is destinated to replenish the progenitor cell pool. Another exciting phenomenon that is largely discussed in scientific literature is stem cell plasticity. In the widest sense, plasticity describes the possibilty of any cell, regardless of its state of differentiation, that with or without cell division can aquire the morphology, phenotype and/or function of another cell. For example, a morphologicaly non recognisable erythroid progenitor cell becomes an erythroblast and further on an erythrocyte. In terms of stem cell biology, plasticity often means that stem or progenitor cells have intra-tissue and/or inter-tissue plasticity or trans-differentiation potential. Intratissue plasiticity referes to the transformation of lineage restricted, but not fully differentiated cells, to a cell of another tissue specific lineage. For example, it has been demonstrated that progenitor cells of myeloid and lymphoid lineage could transdifferentiate to each other during their developmental pathways [1,2]. The example of inter-tissue plasticity is the putative HSC potential to give rise to connective tissue cells like chondrocytes, osteoblasts and adipocytes [3] or putative MSC potential to trans-differentiate across germ layer specificity into neurons or hepatocytes [4]. The experimental evidences for stem cell plasticity mostly derive from in vitro experiments and it is precocious to consider that intra-tissue and inter-tissue plasticity is a rare event that could be triggered during different pathologies in vivo [5]. Indeed, many cases of trans-differentiation could be explained through cell fusion that occurs between 
donor and damaged recipient cells in a process know as "rescuing" [5]. The other important challenge in plasticity research is matching the phenotype of isolated cells with their function. If more than one cell is transplanted, the possibility that cells have distinct differentiation potential, even with same phenotype, is present. If the issue is bone marrow or blood, the versatility of cell types is high, and these tissues are frequently reported to have multi- or pluripotent cells [3]. This brief review of stem and progenitor cell characteristics should be useful for understanding the complexity and nature of stem and progenitor cells (SPCs) found in the blood.

\section{Bone marrow harbor stem and progenitor cells in specific niches}

During prenatal development HSCs leave the fetal liver and spleen to colonize the bone marrow, which is the unique HSC niche during postnatal life. While residing in the fetal liver and spleen, HSCs cycle continuously and produce a large pool of hematopoietic stem and progenitor cells (HSPCs), able to repopulate the bone marrow. Long term repopulating HSCs are a small population of true stem cells that are exclusively characterized by the in vivo ability to repopulate the bone marrow of secondary recipients after serial transplantations, gracely to their self-renewal capacity. In adult bone marrow, during steady-state, long term repopulating HSCs divide once in 2.5 weeks in mice and cat and once in 40 weeks in humans, and this low proliferative activity is related to their life-long stemness potential [6]. HSCs quiescence and cycling activity, as well as self-renewal, differentiation, survival and migration are regulated through the contact with bone marrow stromal cells, extracelullar matrix (ECM), cytokines/growth factors and physicochemical factors like $\mathrm{pH}$ and concentration of oxygen and $\mathrm{Ca}++$ [7-9]. Beside HSCs, the bone marrow harbors an important population of MSCs that differentiate to stromal osteoblasts and adipocytes. Other niche cells are adventitial reticular cells/pericytes, endothelial cells, endothelial progenitor cells and a large number of hematopoetic progenitors and precursors that have seeded the bone marrow during the prenatal development (Figure 1). Some of ligand/receptor complexes that provide the maintainance of HSC inducing their quiescence are Angiopoietin/Tie-1, Stem Cell Factor/c-kit, MPL/Thrombopoietin and TGF- $\beta /$ TGF- $\beta$ R. Self-renewal is promoted through Notch signaling. HSC, EPC, MSC and fibrocyte mobilization from the bone marrow and homing to the bone marrow or other tissues in a regulated manner is organized through a complex network of adhesion and signaling molecules $[9,10]$. 


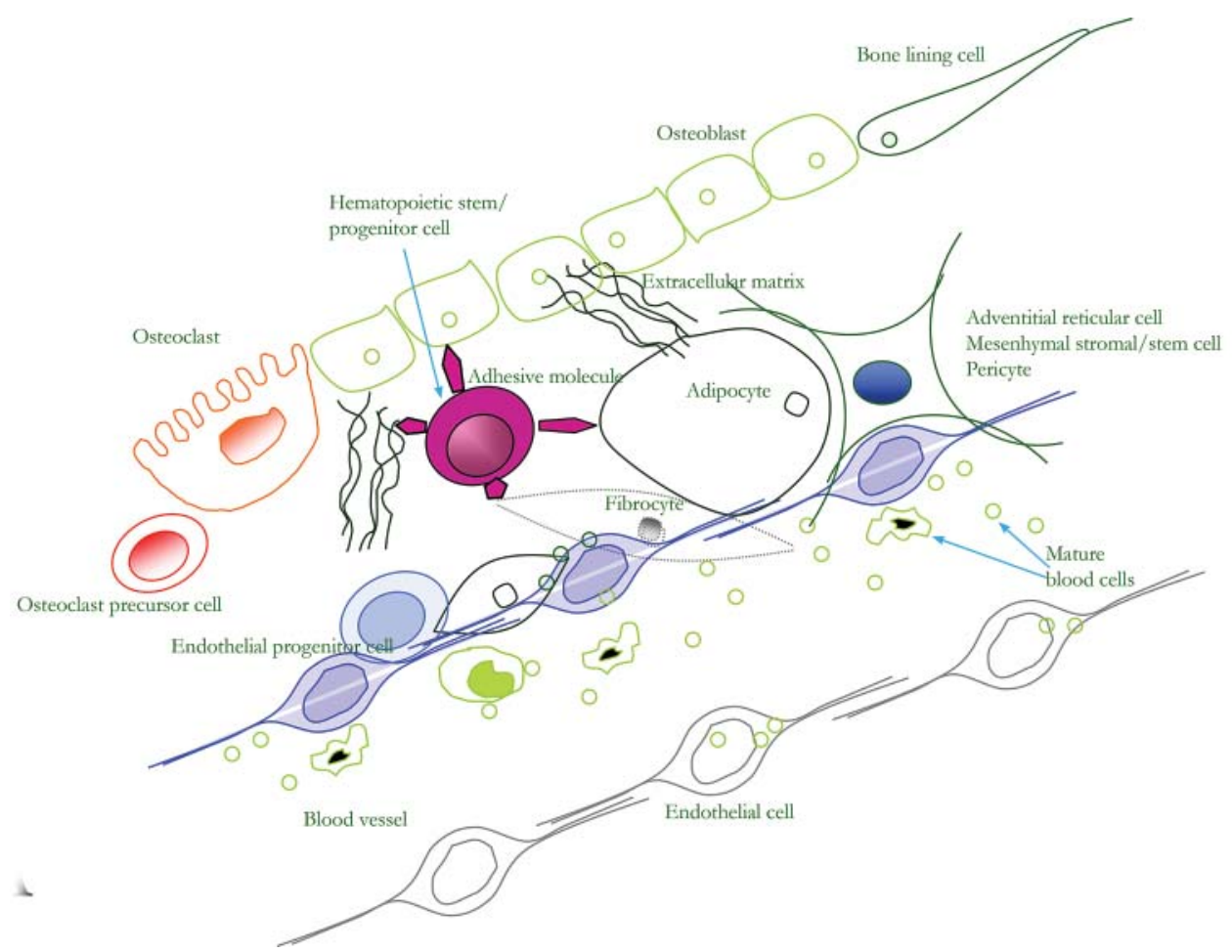

Figure 1. Bone marrow niche harbors different stem/progenitor cell populations in steadystate.

\section{Mobilization and homing of stem and progenitor cells}

Mobilization is a process of SPCs egress from their tissue niche to the blood (Figure 2). Homing is a mechanism by which SPCs circulating in the blood enter the connective tissue of specific organs, while engraftment is homing with restoration of specific cell functions. In the steady-state, HSPCs re-enter bone marrow, but the destiny of mesenchymal stem/progenitor cells (MSPCs) and other SPCs is not clear yet. During tissue injury, all mobilized cells are recruited to the sites of inflammation [10].

The current view is that the most important axe in the SPCs mobilization and homing is the balance between Stromal Derived Factor-1 (SDF-1), a small chemokine predominantly syntetized by fibroblasts and osteoblasts in the bone marrow, and bioactive lipid Sphingosine 1-Phosphate (S1-P) released mainly by blood components [11]. During stress reactions the level of SDF-1 decreases and that of S1-P increases, favoring SPC mobilisation. The major SDF-1 receptor is CXCR4, a molecule expressed on different bone marrow stromal cells including all types of SPCs [11]. The receptor for S1-P is S1-P 1 [11]. SDF-1 level in the bone marrow, as well as number of HSPCs in the circulation are inversely related and have a circadian rhythm governed through noradrenaline secretion by the sympathetic nervous system and thus HSPC number in the peripheral blood peaks $5 \mathrm{~h}$ after the initiation of light and reaches a nadir $5 \mathrm{~h}$ after 
darkness [9]. Other molecular complexe that influence SPCs mobilization and homing are the very late cell adhesion molecule 4 (VLA-4) on stem cells and the vascular cell adhesion protein 1 (VCAM-1/ CD106) on pericytes and endothelial cells [12]. Stem cell factor, erythropoietin, stress and exercise also mobilize different SPCs and the significance of these findings remains to be determined. The recent discovery that reduction of endogenious prostaglandin E2 levels with NSAID, augments the number of HSPCs in the circulation, should be of great clinical interest [13].

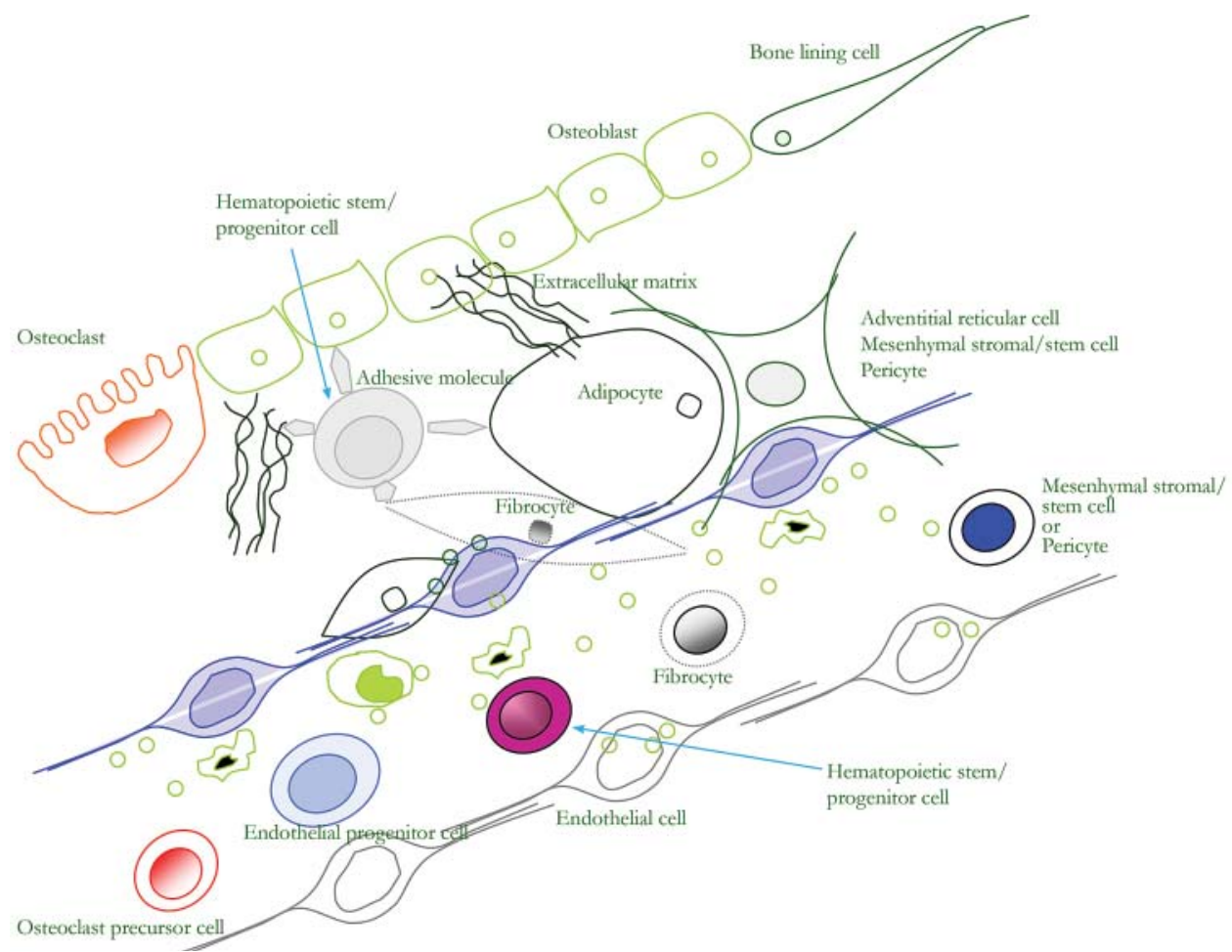

Figure 2. Mobilization of stem/progenitor cells from the bone marrow niche into the blood is modulated with Stromal Derived Factor-1 and different mobilizing agents.

Inflammation and stress modulate the responsivness of all cells and tissues and upregulate many signaling molecules. Pro-inflammatory cytokines like granulocyte colony stimulating factor (G-CSF), granulocyte-monocyte colony stimulating factor (GMCSF), IL-8 and tumor necrosis factor alfa (TNF- $\alpha$ ) are well known mobilizing agents [12]. Some data indicate that during inflammation MSPC mobilization and homing to injured tissues is mainly governed throught TGF- $\beta$ action [14]. The discovery of these multiple pathways that regulate the mobilization and homing of SPCs led to introduction of succesfull stem cell treatments in human medicine, an issue that will be discussed later in this review. 


\section{Blood hematopoietic stem and progenitor cells from embryo to adult life: classics with a tinge of exotics}

Peripheral blood is the blood obtained from standard venepuncture sites. This term is introduced to contrast the blood obtained with bone marrow aspiration and is colloquial in HSCs transplanation. The presence of HSPCs has been proven in the peripheral blood of steady-state adult mice soon after the first big achievement in experimental hematology that used the in vivo repopulation assay to define functional stem cells properties of bone marrow cells $[15,16]$. Now it is clear that under steadystate, HSPCs egress into peripheral blood in a circadian rhythm governed by local sympathetic nerves sprouting the vasculature and SDF-1/S1-P axe [9]. The site of their homing without any pathological event is not so clear, but current evidence suggests that HSPCs traffic for several days through various extramedullary tissues, draining through the lymphatic circulation to reach again the blood and bone marrow [17]. Much more is known about HPSC mobilization as a consequence of different types of stress and inflammation that lead to HPSC recruitment to the sites of tissue injury [18].

Although CD34+ multipotent myeloid/lymphoid progenitor cells have been widely demonstrated in the blood of humans and different animals, the first experimental evidence for the presence of long-term repopulating HSCs within human steady-state peripheral blood CD34+ cells is enabled with the use of leukoreduction filters that concentrate mononuclear cells from the blood [19]. Several years ago, in soldiers that received blood transfusions during World War II and in Vietnam War, the existence of long-term repopulating HSC in adult steady-state peripheral blood was proved, by donor type microhimerism [20]. The physiologic significance of long-term repopulating HSCs circulating through the blood in the steady-state condition is not known, but maintenance of HSCs pool in all active sites of hematopoiesis could be one of the explanations.

One of the obvious physiological reasons for progenitor cell egress from the bone marrow is the case of lymphoid lineage. Lymphoid-specified multipotent progenitors primed for $\mathrm{T}$ lineage, constantly leave the bone marrow and replenish the thymus in a life long need for T lymphocyte development [1]. Different maturational stages of B lymphocytes and dendritic cells also leave the bone marrow and traffic to different secondary lymphatic organs and target tissues maintaining immunity indispensable for animal/human survival [2].

The number, phenotype and functional characteristics of myeloid progenitors in the peripheral blood are described in many animal species and humans, but they are still the focus of intensive research. This is mainly due to their putative role in the pathogenesis of various disease and escalating interest in HSPC plasticity. Myeloid progenitors could be demonstrated in vitro using semisolid media and adequate growth factors. Colony forming unit - granulocyte/monocyte (CFU-GM) is a myeloid progenitor cell that forms large colonies of granulocytes and monocytes and is found 
in the bone marrow and peripheral blood. One CFU-GM isolated from pig peripheral blood is presented on Figure 3a. Although the number of CFU-GM in the peripheral blood is small in steady state condition [21], pro-inflammatory molecules enchance proliferation, differentiation and maturation of bone marrow CFU-GM and rapid mobilization of these cells to the peripheral blood [18]. Mobilized CFU-GM could be recruited to the sites of inflammation in large numbers. For example, after infection with Schistostoma mansoni, thousands of eggs flud the liver periportal venous radiculi and induce the formation of granulomas that become a place of active myelopoiesis [22]. After an experimental infection with the mentioned parasite, the number of myeloid progenitors in the whole liver was equivalent to half of their content in the femur [22]. Also, myeloid progenitors home to sites of allergic reaction and it is proposed that stimulation with local cytokine milieux influence their differentiatiation in situ to eosinophiles and basophils [18]. Although all initial studies leading to the discovery of bone marrow HSPCs have been done in canines, no studies on dogs, or other large animals, have been done concerning the role of myeloid progenitors in different pathologies.

The number of steady-state erythroid progenitors in the peripheral blood, estimated in pigs, is around a hundred times lower than the number of these progenitors in the bone marrow [23] and their proliferative activity is lower comparing to counterparts in the bone marrow indicating on the possibility that the cell cycle status influences their migration/mobilization possibilites [24]. Massive mobilization of erythroid progenitors from the bone marrow is stimulated in hemolitic or hemoragic anemia [25], as well as in different types of myeloproliferative disorders [26] that are also connected with extramedullary, i.e. splenic, erythropoiesis [27]. Althought it seems logical that mobilized erythroid progenitors would home to the spleen and other organs

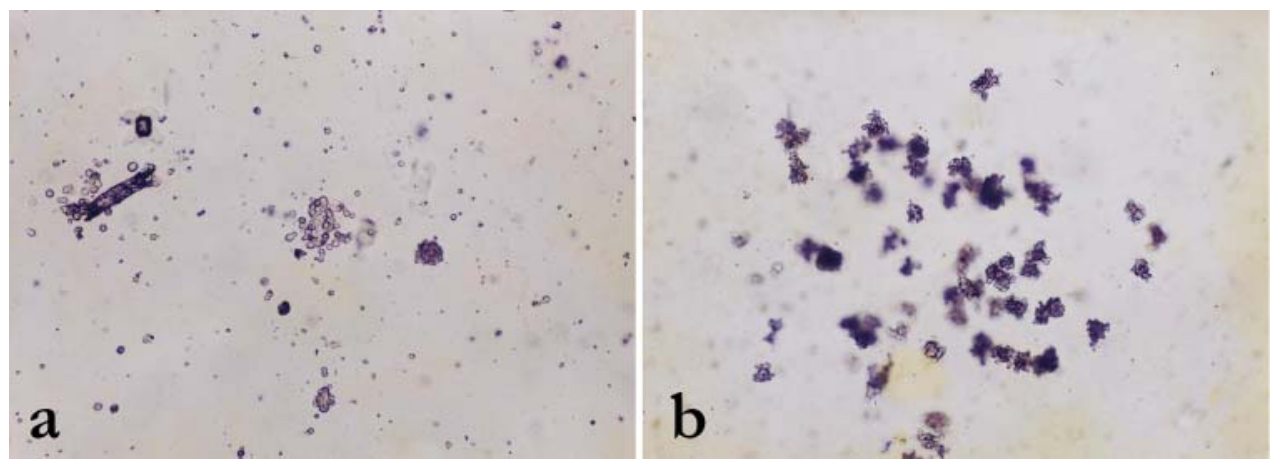

Figure 3. Peripheral blood mononuclear cells were seeded on semi-solid medium (methylcellulose) with combination of growth factors. After 10 days of cultivation $\left(5 \% \mathrm{CO} 2,37^{\circ} \mathrm{C}\right)$, committed progenitors named Colony Forming Unit - Granulocyte Monocyte (CFU-GM) formed colonies of several hundreds myeloblasts (a). Committed progenitors named Burst Forming Unit - Erythroid (BFU-E)formed colonies of several thousands of hemoglobinized erythroblasts (b). Magnification 4x. 
with a microenvirnoment permissive for hematopoiesis/erythropoiesis, experimental evidence in mice point to the existence of particular self-renewing spleen erythroid progenitor clones, that rapidly responde to the stimulus with a fast proliferation and maturation toward erythrocytes [28]. The importance of erythroid progenitor mobilization to the peripheral blood remains to be delineated. Morphology of Burst Forming Unit - Erythroid (BFU-E) colony representative for erythroid progenitor lineage is presented on Figure $3 \mathrm{~b}$.

Megakaryocyte progenitor cells were found in the peripheral blood of humans [29] but no studies have been done in large animals. The megakaryocyte progenitor number rises in the blood after mobilization with G-CSF [30]. These cells express CXCR4, the main HSPC homing receptor, meaning that they are capable of homing [30]. Bone marrow is probably the only homing tissue of megakaryocyte progenitors, albiet functional megakaryocytes could be found in the spleen and lung. The significance of megakaryocyte progenitors in the blood remains to be determined.

Circulation of HSPCs in the blood and lymphatics makes a continuum with embryonal HSPC traffic. Definitive HSCs responsible for life-long production of mature blood cells, are formed in a short time window of embryo development, lasting around 3 days in mice (day 8,5 to 12). Currently, the view that the dorsal aorta endothelial cells are the source of definitive HSCs is supported with real time capture of HSCs budding from this location and the process is defined as endothelial-to-hematopoietic transition [31]. This hemogenic endothelium derives from intra-embryonic paraaortic splanchnopleural mesoderm, which contributes to the developing dorsal aorta in the aorta gonada mesonephros (AGM) region [32]. Fetal liver, spleen, thymus and finally bone marrow have not the capability to generate HSCs, but become colonized with HSCs formed in the AGM region via circulation because they possess the microenvironment which is suitable for further HSPC expansion and maturation to different blood cell lines [33, 34]. It is interesting that transplantation studies using green fluorescent protein (GFP) labeled endothelial progenitor cells derived from the bone marrow demonstrate that donor type EPC not only take part in vasculogenesis, but also retain their hematopoietic ability in recipient mouse, supporting the view that the hemogenic endothelium is present during the entire lifespan [35].

\section{Peripheral blood hematopoetic stem and progenitor cells are used in cell therapy}

The genuine ability of HSCs to colonize/repopulate the myeloablated bone marrow and maintain life long blood formation is largely used as the principal or facultative therapy in many hematologic and non hematologic deseases in humans. The discovery that HSPCs reside in the peripheral blood led to the blood born stem cell transplantation concept that today has a history of almost 30 years of practice [36]. The number of peripheral blood HSCs in the steady-state is inadequate for therapeutic purposes. First pharmaceutical agents discribed to mobilize HSPCs were cyclophosphamide and 
adriamycin [37]. This and later findings opened the gate for important progress is stem cell therapy enabling shifting of HSPC harvest from bone marrow to peripheral blood [36]. For the last 20 years, G-CSF was successfully used in cell therapy mobilization protocols, augmenting the HSPC yield by 60 to 100 folds in the majority of cases [38]. Some patients are designated as non-responders or ,poor“ mobilizers based on a low number of peripheral blood HSPCs after G-CSF treatment [39]. The new agent that resolved the problem of ,poor" mobilizers is Plerixafor, a molecule which reversibly inhibits SDF-1 binding to CXCR4, efficiently promoting HSC mobilization [12].

In year 2011 in Europe, the majority of allogenic HSPC transplantations $73 \%$ of 13.470) and all autologous HSPC transplantations have been done using peripheral blood derived cells ( $99 \%$ of 18.605) [40]. Cord blood has been used in $6 \%$ of allogenic transplantation and non for autologous transplantation [40].

Recently, it was suggested that steady-state HSPC from peripheral and cord blood could be used as a starting cell population for massive in vitro production of erythrocytes available for transfusion [41] and vaccine development [42]. Moreover, after optimized in vitro expansion protocols, HSPCs isolated from the cord blood, efficently reduced neutropenia after high dose chemotherapy [43].

Lately, several authors have considered autologous peripheral blood HSPC transplantation in dogs with T or B lymphoma $[44,45]$. No statistics on the usefulness of such a therapy could be done due to the low number of cases, but succeful engrafment after specified protocols has been demonstrated [45]. As a result of these succesful transplantations, after 60 years, the dog has finally moved from the status of large animal preclinical model for HSPC transplantation, to being treated as a patient.

Efficient managment of HSPC is possible because of optimized protocols for their cryopreservation. For long term storage, temperatures in the range from $-156^{\circ} \mathrm{C}$ to $-196^{\circ} \mathrm{C}$ are recommeneded [46]. For short term storage not longer than 7 to 10 days, low oxygen and high carbon-dioxide atmosphere at $4^{\circ} \mathrm{C}$ are suggested $[47,48]$.

HSPCs therapy in human medicine was developed during decades and this brief overview is writen with the idea that further research in veterinary medicine is needed in order to develop specific veterinary therapies.

\section{Blood harbors osteoclast precursor cells: exotic cells with classical function}

Once tought to be a unipotent progenitor cell, Colony-Forming Unit - Macrophage (CFU-M) is now defined as a commone progenitor cell for monocytes/macrophages, osteoclasts and dendritic cells [49].

The subpopulation of monocytes/macrophages with a specific phenotype, represent direct osteoclast precursor cells [50]. One of the earliest findings related to osteoclast precursor cells (OPC) was that they travel throught the blood to the bone marrow area where the bone should be resorbed, settle and terminate maturation to functional cells [51]. Their maturation is regulated with osteoblast secreted factors: Macrophage 
- Colony Stmulating Factor (M-CSF), RANKL and osteoprotegerin [52]. SDF1 and S1-P are suggested to play a role in OPC egress and homing during steadystate in mice [53]. The presence of OPC in the cord and peripheral blood could be demonstrated in vitro. OPCs are adherent cells with fibroblast-like morphology that give rise to multinucleated osteoclasts that have tartarate-resistent acid phosphatase (TRAP) activity and express CD45 (pan-leukocyte marker) and CD51/CD61 [54]. It was also demonstrated that the number of osteoclasts in the peripheral blood is increased in patients with erosive osteoarthritis [55] and severe periodontitis [56]. It is interesting that transplantation of OPC into arthritic mice strongly inhibits joint inflammation and suppress $\mathrm{T}$-cell proliferation in vitro [50]. These investigations lead to the conclusion that osteoclasts have an important immunomodulatory role [50]. However, many more informations are needed to complete the puzzle of OPC circulating in the blood.

\section{Endothelial progenitor cells: classical neighborhood cells}

Vasculogenesis is the formation of blood vessels that relays on the differentiation of mesodermal cells to endothelial progenitor cells (EPC) mainly during embryonic development. Angiogenesis is a process of capillary sprouting from preexisting blood vessels which takes place during the lifespan. The intra-embryonic origin of EPC is complex: paraaortic splanchnopleural mesoderm have bipotent cells with the capacity to differentiate to HSC and EPC (hemogenic endothelium), whereas somites produce only EPC [57]. HSC and EPC also arise in avian placenta (allantois) and reach fetal bone marrow via blood [58]. It is a matter of debate if these cells are distinct HSCs and EPCs or placenta generated hemangioblasts, putative bipotent common hematopoietic and endothelial stem cells [58]. The intimate spatial and temporal relationship of HSC and EPC appearance during prenatal development and expression of same molecules (CD34+, Vascular Endothelial Growth Factor Receptor) are the roots of the idea that these cells have the common ancestral cells even in postnatal life.

The first paper that established the idea about the presence of EPCs in the blood of adult humans and mice has been published in 1997 [59]. The source of EPC is considered to be the bone marrow, vascular adventitia and endothelium itself [60]. EPCs have been found among low proliferative, spindle shaped, adherent CD34(+) cell population that after 5 days of specific culturing conditions ingested acetylated low density lipoproteins (acLDL), produced nitric oxide upon acetylcholine stimulation and had a phenotype slightly different in comparison to the originally seeded cell population [59]. Asahara and coworkers [59] also provided evidence that after acute vascular injury, EPCs substantially contribute to the regeneration or repair of vascular structures in injured/ischemic tissues. Recently a more precise molecular and functional sorting of peripheral blood mononuclear cells identified a small fraction of cells (CD146+, CD34+, CD31+, CD45-, CD133-) named Endothelial ColonyForming Cells (ECFCs) that have robust proliferative potential and may incorporate into perfused vessels in vivo suggesting their true progenitor nature [60]. It is interesting 
to note that pro-angiogenic, low proliferative, blood derived monocytes, or other hematopoietic cell subsets endowed with plasticity inherent to mesodermal cell lineage, could transitionally express endothelial phenotype, but without permanent incorporation into the newly formed vessels $[61,62]$. One should keep in mind that plasticity also depends on culturing conditions and that these conditions influence the phenotype and probably the function of isolated cells.

The view that many pathological conditions could benefit from the inhibition or stimulation of vasculogenesis and angiogenesis was supported by multiple investigations [63-65]. However, some apparently contradictory findings have marked EPC research. Initially, blood born EPCs were seen as protectors of atherosclerotic vessels as they have the ability to replace damaged endothelial cells [66]. Some recent findings demonstrate that adult human peripheral blood contains EPCs identified to co-express osteoblastic surface markers [67]. These "distorted" EPCs are recruited to the injured vascular tissue and contribute to calcification during atherosclerotic processes [67]. Based on this research, down-regulation of the osteogenic phenotype in patients with particular disease prone state is envisaged [68]. Interestingly, EPCs have been reported to easily trans-differentiate to fibroblast and substantially contribute to cardiac fibrosis [69]. Altogether, it seems that EPCs possess high plasticity and potentially are involved in both, beneficial and pathologic tissue response to injury.

Peripheral blood EPCs have not gained attention in veterinary medicine, but large animal models are interesting for preclinical testing of EPC therapeutic potential in various pathological conditions. Although it is estimated that dogs, pigs and sheep are reliable pre-clinical models of ischemic heart disease, their use is not common [70]. One of the rare studies was designed to evaluate the best injection modality for improvement of EPC retention in the myocardium after provoked myocardial infarction in dogs [71]. The other one, designed as a pre-clinical testing in pigs, evaluated implantable cardiovascular devices that should be re-endothelialized with autologous EPCs prior to implantation [72]. These examples underline that large animals are interesting as a model for stem/progenitor cell therapy, with respect to replacement, refinement and reduction of animals in research. On the other side, pets are increasingly becoming a target for stem cells therapy, calling for further research in this area in veterinary medicine.

\section{Mesenchymal stem cells: non expected guests in unusual place}

MSCs, like HSCs, derived from the mesodermal cell layer and during postnatal life reside within the bone marrow and other connective tissues. In opposition to HSCs that proliferate in suspension cultures, MSCs are adherent to plastic and ECM components. In serial articles published during the seventh and eight decade of the twentieth century, Alexander Friedenstein demonstrated the existence of skeletal tissue stem cells in the bone marrow [73-75] which later on were named mesenchymal stem cells [76]. Friedenstein and coworkers [75] isolated bone marrow stromal cells 
responsible for in vivo transfer of the hematopoietic tissues microenvironment. They also demonstrated their clonal nature in vitro and called these cells Colony Forming Unit - Fibroblast (CFU-F) [74]. Their osteogenic and chondrogenic capacity has been demonstrated by the same group [73,74]. Another interesting phenomenon, reported in specific culture conditions, is MSCs immunomodulatory and anti-inflammatory capacity, that could be beneficial to the patient suffering of othervise detrimental inflammation [9]. Although in vitro characteristics of MSCs are well know, their in vivo localisation and their exact roles in the steady-state are still a matter of debate and exciting field of research.

Generally, skeletal tissues, like bone and cartilage, were thought to regenerate or repair exclusively trought proliferation and differentiation of MSC residing in the specific tissue niches, migrating locally, independent of blood flow. Surpisingly for adherent cell type, MSC were detected in adult peripheral and cord blood. First article demonstrating presence of CFU-F in the culture of nucleated blood cells was published by Friedenstein's group [77]. Afterwards, the presence of adherent stromal cells in the peripheral blood with the phenotype pointing to their non hematopoietic nature (CD14-, CD34-, collagen type I, III and VI and ICAM (CD54) and VCAM (CD106), CD105 and CD73-) was confirmed in breast cancer patients subjected to G-CSF mobilization protocol [78]. Although some authors have not been able to recover MSCs from human peripheral blood [79, 80], others supported the finding that MSCs circulate even in the steady-state. In the peripheral blood mononuclear cell fraction, containing mostly monocytes, on a sample of 100 donors, MSC were found at a frequency of $0.3-0.7 \%$ and their osteogenic and adipogenic potential was demonstrated [81]. In particular, the interest to examine different animal models was highlighted in research demonstrating that circulating MSCs are more frequent among rodents comparing to man [82] and that specifically peripheral bood of guinea pigs harbor stromal progenitors or precursors that are exclusively chondrogenic [83]. If these circulating chondrogenic progenitors could home to cartilage, they might contribute to the high ability of articular cartilage self-repair in guinea pigs [83]. Except peripheral blood, cord blood is also a source of undifferentiated stromal cells. However, cord blood is heterogeneous in regard to stem cell content and expression of pluripotency markers (Sox2 and Nanog4) [84]. Only large volumes of cord blood contain enough MSC to establish in vitro culture, making overall efficiency of cord blood MSC isolation quite low [84].

Isolation and culturing of peripheral blood MSCs in domestic animals was quite successful. Dog peripheral blood MSC were isolated from $20 \mathrm{~mL}$ of heparinized blood and were seeded in adherent culture supplemented with IL-6 [85]. After several passages, adherent cells where CD34-/low, osteocalcin+ [85]. In the same experiment [85], autotransplantation of GFP transfected adherent cells was done after total body irradiation. Fifteen weeks after transplantation, GFP was expressed in osteoblasts lining the bone and small number of circulating mature blood cells, indicating MSC engraftment in the bone marrow, differentiation toward osteoblasts and egression of 
one subset of cells into the peripheral blood [85]. More recently, canine cord blood MSCs were used to improve ossteointegration between the dental implant and the walls of the alveolar bone [86]. Their osteogenic potential was demonstrated to be high [87], as well as the potential for regeneration/repair of spinal cord after injury $[88,89]$. This later observation could further be explained with the existence of a small subset of cord blood MSCs that express pluripotent stem cell markers (Oct4, Nanog, Sox 2) and possess an inherent neurogenic potential [84].

In horses, peripheral blood stromal/adherent cells were first isolated under steady state conditions in 2006, but with poor in vitro performances concerning differentiation potential [90]. Afterwards, an optimized protocol has led to the establishment of peripheral blood MSCs with trilineage differentiation potential [91]. Equine cord blood MSCs were isolated with very low frequencies - one to five primary colonies per sample, with trilineage potential, but no phenotypisation has been done [92]. In a case control study, peripheral blood mononuclear cells, conditioned for $72 \mathrm{~h}$ with M-CSF and separated based on CD90 and CD117 expression, were successfully used for therapy of superficial digital flexor tendon injuries in three horses [93]. In another study, safety of intravenous injection of allogenic peripheral blood MSC was evaluated on 291 horses and no adverse reactions were found either during short or long term (one year) monitoring [94]. It is surprising that only these five articles focused peripheral and cord blood MSCs in horses as this species seems to be the most frequently targeted for MSC therapy. This therapy is simply called „stem cell therapy" and expands in an uncontrolled manner, with more than 10,000 hints since 2010 only in USA [95].

The possible roles of MSCs recruited into the blood are most probably regeneration and repair of different tissues suffering some kind of damage. One of the experiments trying to clarify MSC role in myocardium regeneration/repair used the myeloablated wild type mice transplantated either with whole bone marrow cells or separated HSCs from GFP transgenic mice [96]. After bone marrow reconstiution, myocardium infarcts have been provoked and HSC have been G-CSF mobilized. After 8 weeks, animals rescued with whole bone marrow had an important number of GFP cardiomyocites, while animals rescued with HSCs did not have GFP postitive cells in the heart [96]. This experiment demonstrated that probably MSCs could regenerate myocardial tissue and that their source is the bone marrow, althought a role of other SPCs could not be excluded. On the contrary to this beneficial effect, MSC recruited to the blood under influence of transforming growth factor $\beta 1$ (TGF- $\beta 1$ ) released from injured arteries, homed in injured tissue and contributed to osteogenic vascular calcification [14].

Concerning all stated, peripheral and cord blood MSCs seem to be important for veterinary medicine. Moreover, if not an artifact, easy isolation of MSCs from the animal blood could ameliorate research in this area to be further translated to human medicine. 


\section{Circulating fibrocyte: the cell in between}

Historically, the nomenclature "fibrocyte" was reserved for sessile connective tissue cells that do not have an obvious synthetic activity when compared to fibroblasts. Also, the origin of fibrocytes/fibroblasts was believed to be uniquely mesenchymal. First data reporting on the existence of circulating fibrocytes (fibroblast and monocyte) provided evidence that one part of adherent blood cells co-express monocyte $(\mathrm{CD} 14+, \mathrm{CD} 11+)$, pan-leukocyte $(\mathrm{CD} 45+)$ and hematopoietic stem and progenitor cell markers $(\mathrm{CD} 34+)$ together with markers of non-differentiated and differentiated mesenchymal cells: pro-collagen type I and vimentin. These cells comprise $0.1-0.5 \%$ of the peripheral blood mononuclear cell fraction [97]. These first experiments postulated that fibrocytes derive from a radioresistant bone marrow stromal population (hematopoetic cells are radiosensitive) that is mobilized to blood and homes to the site of tissue injury, undergoing differentiation to fibroblast-like cell thus playing a role in scar formation [97]. Further evidence advocated hematopoietic origin of fibrocytes due to expression of the major histocompatibility complex class I and class II, the costimulatory molecules CD80 and CD86 and a role in antigen presentation, typical for myeloid cell lineages [98]. A number of studies, using transplantation of GFP+ HSC into GFP- recipient mice, delineated number of tissues/locations (kidney, heart, inner ear, brain microglia) with GFP+ fibroblasts or myofibroblasts after intervention [3]. The most recent study conducted on mice expressing RFP (red fluorescent protein) in non hematopoetic cells and GFP in hematopoietic cells, demonstrated that two distinct hematopoietic cells (one CD45+ and other CD45-), mobilized from the bone marrow, transitionally depose ECM at the wound site disappearing after wound healing [99].

Circulating fibrocytes gained attention because of their positive impact to wound healing through deposition of ECM, secretion of pro-angiogenic and pro-inflammatory cytokines and antigen presentation $[98,100]$. Their own recruitment to wounds or sites of chronic inflammation is mediated through the expression of multiple chemokine receptors $[33,101,102]$. Research done in the last 20 years, accumulated evidence that circulating, bone marrow derived fibrocytes, play an important role in pathological fibrosis that could affect different organs like the lung, liver, myocardium, kidneys and bone marrow itself [103]. Inhibition of fibrocyte differentiation in experimental mice and rat models of lung fibrosis led to reduction in fibrotic lesions [104].

Pathological fibrosis is of interest in small animal practice [105-107], as well as in horses [108] and wild animals [109]. Also, using a comparative natural-occurrence disease model approach, pathological fibrosis in large animals was suggested to be interesting for further research in human disorder pathogenesis [110]. Many research articles combine different approaches to highlight some pathological phenomenon related to tissue injury and regeneration [111-113]. Although the interest to unravel mechanisms of pathological fibrosis in veterinary medicine is evident, and possibilities to find a good model to investigate circulating fibrocytes' nature and function are multiple, these curious cells have not been investigated in large animals, yet. 


\section{Enchanting diversity leads to imagination}

Except all decribed cell populations, some investigators report that pericytes [114], vascular smooth musle progenitor cells [115] and osteogenic precursor cells [116]. Mostly based on Ratajczak and his group research, very small embrionic-like stem cells (VSELCs) have been shown to mobilize from the bone marrow to the blood and recruite to the sites of tissue injury [117]. VSELCs are able to differentiate into cells of all germ layers [117]. Concerning all different SPCs that could be found in the blood, historical mythes of blood regenerative potentials could be envisaged to be truly possible.

\section{CONCLUSION}

The blood, as well as the bone marrow, have highly versatile stem and progenitor cell population that represent the whole armamentarium promptly recruited as a response to tissue injury. In steady-state, re-circulation of HSPCs, MSPCs, EPCs, OPC, fibrocytes, pericytes and VSELCs, is probably related to the surveillance of tissue homeostasis. Apparently, during tissue injury, fast recruitment of these potent cells has an effect on the regulation of inflammatory reactions or to injured tissue regeneration. Some circumstances during inflammation probably trigger signaling that distort SPCs to a non desirable functional phenotype that could be detrimental to the patient. The fact that HSPCs are travelling in the blood is used in human medicine for several decades in the protocols for therapy of different pathologies. In veterinary medicine, this field of research just started to be exploited.

\section{Acknowledgment}

The author is very grateful to Dr Zoran Ivanović, Director of R\&D, AquitaineLimousin Branch of French Blood Institute and Dr Tatjana Božić, Professor at Patophysiology at Faculty of Veterinary Medicine University of Belgrade, for critical reading of this work.

Funding source: This work was supported by a project of the Ministry of Education, Science and Technological Development, Republic of Serbia (No. 175061).

\section{REFERENCES}

1. Lai AY, Kondo M: Identification of a bone marrow precursor of the earliest thymocytes in adult mouse. Proc Natl Acad Sci U S A. 2007, 104(15):6311-6.

2. Mortellaro A, Wong SC, Fric J, Ricciardi-Castagnoli P: The need to identify myeloid dendritic cell progenitors in human blood. Trends Immunol. 2010, 31(1):18-23.

3. Ogawa M, Larue AC, Watson PM, Watson DK: Hematopoietic stem cell origin of connective tissues. Exp Hematol. 2010, 38(7):540-7. 
4. Phinney DG, Prockop DJ: Concise review: mesenchymal stem/multipotent stromal cells: the state of transdifferentiation and modes of tissue repair--current views. Stem Cells. 2007, 25(11):2896-902.

5. Theise ND: Stem cell plasticity: recapping the decade, mapping the future. Exp Hematol. 2010, 38(7):529-39.

6. Catlin SN, Busque L, Gale RE, Guttorp P, Abkowitz JL: The replication rate of human hematopoietic stem cells in vivo. Blood. 2011, 117(17):4460-6.

7. Adams GB, Chabner KT, Alley IR, Olson DP, Szczepiorkowski ZM, Poznansky MC, Kos $\mathrm{CH}$, Pollak MR, Brown EM, Scadden DT: Stem cell engraftment at the endosteal niche is specified by the calcium-sensing receptor. Nature. 2006, 439(7076):599-603.

8. Kovačević-Filipović M, Petakov M, Hermitte F, Debeissat C, Krstić A, Jovcić G, Bugarski D, Lafarge X, Milenković P, Praloran V, Ivanović Z: Interleukin-6 (IL-6) and low O(2) concentration $(1 \%)$ synergize to improve the maintenance of hematopoietic stem cells (pre-CFC). J Cell Physiol. 2007, 212(1):68-75.

9. Frenette PS, Pinho S, Lucas D, Scheiermann C: Mesenchymal stem cell: keystone of the hematopoietic stem cell niche and a stepping-stone for regenerative medicine. Annu Rev Immunol. 2013, 31:285-316.

10. Liu ZJ, Zhuge Y, Velazquez OC: Trafficking and differentiation of mesenchymal stem cells. J Cell Biochem. 2009, 106(6):984-91.

11. Golan K, Vagima Y, Ludin A, Itkin T, Cohen-Gur S, Kalinkovich A, Kollet O, Kim C, Schajnovitz A, Ovadya Y, Lapid K, Shivtiel S, Morris AJ, Ratajczak MZ, Lapidot T: S1P promotes murine progenitor cell egress and mobilization via S1P1-mediated ROS signaling and SDF-1 release. Blood. 2012, 119(11):2478-88.

12. Hopman RK, DiPersio JF: Advances in stem cell mobilization. Blood Rev. 2014, 28(1):31-40.

13. Hoggatt J, Mohammad KS, Singh P, Hoggatt AF, Chitteti BR, Speth JM, Hu P, Poteat BA, Stilger KN, Ferraro F, Silberstein L, Wong FK, Farag SS, Czader M, Milne GL, Breyer RM, Serezani CH, Scadden DT, Guise TA, Srour EF, Pelus LM: Differential stem- and progenitor-cell trafficking by prostaglandin E2. Nature. 2013, 495(7441):365-9.

14. Wang W, Li C, Pang L, Shi C, Guo F, Chen A, Cao X, Wan M: Mesenchymal Stem Cells Recruited by Active TGF $\beta$ Contribute to Osteogenic Vascular Calcification. Stem Cells Dev. 2014, in press.

15. McCulloch, Till JE. The radiation sensitivity of normal mouse bone marrow cells, determined by quantitative marrow transplantation into irradiated mice. Radiat Res. 1960, 13:115-25.

16. Goodman JW, Hodgson GS: Evidence for stem cells in the peripheral blood of mice. Blood. 1962, 19:702-14.

17. Massberg S, von Andrian UH: Novel trafficking routes for hematopoietic stem and progenitor cells. Ann N Y Acad Sci. 2009, 1176:87-93.

18. Fischer KD, Agrawal DK : Hematopoietic Stem and Progenitor Cells in Inflammation and Allergy. Front Immunol. 2013, 4 (4):428.

19. Utter GH, Lee TH, Rivers RM, Montalvo L, Wen L, Chafets DM, Reed WF, Busch MP: Microchimerism decades after transfusion among combat-injured US veterans from the Vietnam, Korean, and World War II conflicts. Transfusion. 2008, 48(8):1609-15

20. Brunet de la Grange P, Vlaski M, Duchez P, Chevaleyre J, Lapostolle V, Boiron JM, Praloran V, Ivanovic Z: Long-term repopulating hematopoietic stem cells and "side population" in human steady state peripheral blood. Stem Cell Res. 2013, 11(1):625-33. 
21. Kovačević M, Božić T, Jovčić G, Petakov M, Bugarski D, Stanković J, Ivanović Z: 2001. Pig bone marrow and peripheral blood granulocyte-macrophage progenitor cells. Acta Veterinaria (Beograd), 51(1): 15-26.

22. Dutra HS, Rossi MI, Azevedo SP, el-Cheikh MC, Borojevic R: Haematopoietic capacity of colony-forming cells mobilized in hepatic inflammatory reactions as compared to that of normal bone marrow cells. Res Immunol. 1997, 148(7):437-44.

23. Kovačević M, Božić T, Ivanović Zoran: Erythroid progenitor cells from pig bone marrow and peripheral blood. Veterinary Journal. 1999, 158: 196-203.

24. Kovačević M, Božić T, Pavlović V, Petakov Marijana, Bugarski Diana, Jovčić Gordana, Ivanović Zoran: Pig bone marrow and peripheral blood erythroid progenitor cells in $\mathrm{S}$ phase of the cell cycle. Acta Veterinaria (Beograd) 2000, 50 (4): 207-214.

25. Brockbank KG: Circulating erythroid progenitors in normal and anemic rabbits. Blut. 1983, 47(3):131-7.

26. Eaves AC, Henkelman DH, Eaves CJ: Abnormal erythropoiesis in the myeloproliferative disorders: an analysis of underlying cellular and humoral mechanisms. Scand J Haematol. 1982, 29(5):373-80.

27. Beguin Y, Fillet G, Bury J, Fairon Y: Ferrokinetic study of splenic erythropoiesis: relationships among clinical diagnosis, myelofibrosis, splenomegaly, and extramedullary erythropoiesis. Am J Hematol. 1989, 32(2):123-8.

28. Paulson RF, Shi L, Wu DC: Stress erythropoiesis: new signals and new stress progenitor cells. Curr Opin Hematol. 2011, 18(3):139-45.

29. Nichol JL, Hornkohl AC, Choi ES, Hokom MM, Ponting I, Schuening FW, Hunt P: Enrichment and characterization of peripheral blood-derived megakaryocyte progenitors that mature in short-term liquid culture. Stem Cells. 1994, 12(5):494-505.

30. Rivière C, Subra F, Cohen-Solal K, Cordette-Lagarde V, Letestu R, Auclair C, Vainchenker W, Louache F: Phenotypic and functional evidence for the expression of CXCR4 receptor during megakaryocytopoiesis. Blood. 1999, 93(5):1511-23.

31. Boisset JC, van Cappellen W, Andrieu-Soler C, Galjart N, Dzierzak E, Robin C: In vivo imaging of haematopoietic cells emerging from the mouse aortic endothelium. Nature. 2010, 464(7285):116-20.

32. Lin Y, Yoder MC, Yoshimoto M: Lymphoid progenitor emergence in the murine embryo and yolk sac precedes stem cell detection: Stem Cells Dev. 2014, 23(11):1168-77.

33. Moore BB, Murray L, Das A, Wilke CA, Herrygers AB, Toews GB: The role of CCL12 in the recruitment of fibrocytes and lung fibrosis. Am J Respir Cell Mol Biol. 2006, 35(2):175-81.

34. Delassus S, Cumano A: Circulation of hematopoietic progenitors in the mouse embryo. Immunity. 1996, 4(1):97-106.

35. Chen C, Zeng L, Ding S, Xu K: Adult endothelial progenitor cells retain hematopoiesis potential. Transplant Proc. 2010, 42(9):3745-9.

36. Körbling M, Freireich EJ: Twenty-five years of peripheral blood stem cell transplantation. Blood. 2011, 117(24):6411-6.

37. Richman CM, Weiner RS, Yankee RA: Increase in circulating stem cells following chemotherapy in man. Blood. 1976, 47(6):1031-9.

38. Socinski MA, Cannistra SA, Elias A, Antman KH, Schnipper L, Griffin JD: Granulocytemacrophage colony stimulating factor expands the circulating haemopoietic progenitor cell compartment in man. Lancet. 1988, 28(8596):1194-8. 
39. Ivanovic Z, Kovacevic-Filipovic M, Jeanne M, Ardilouze L, Bertot A, Szyporta M, Hermitte F, Lafarge X, Duchez P, Vlaski M, Milpied N, Pavlovic M, Praloran V, Boiron JM: CD34+ cells obtained from "good mobilizers" are more activated and exhibit lower ex vivo expansion efficiency than their counterparts from "poor mobilizers". Transfusion. 2010, 50(1):120-7.

40. Passweg JR, Baldomero H, Bregni M, Cesaro S, Dreger P, Duarte RF, Falkenburg JH, Kröger N, Farge-Bancel D, Gaspar HB, Marsh J, Mohty M, Peters C, Sureda A, Velardi A, Ruiz de Elvira C, Madrigal A: European Group for Blood and Marrow Transplantation. Hematopoietic SCT in Europe: data and trends in 2011. Bone Marrow Transplant. 2013, 48(9):1161-7.

41. Vlaski M, Lafarge X, Chevaleyre J, Duchez P, Boiron JM, Ivanovic Z: Low oxygen concentration as a general physiologic regulator of erythropoiesis beyond the EPOrelated downstream tuning and a tool for the optimization of red blood cell production ex vivo. Exp Hematol. 2009, 37(5):573-84.

42. Filippone C, Franssila R, Kumar A, Saikko L, Kovanen PE, Söderlund-Venermo M, Hedman K: Erythroid progenitor cells expanded from peripheral blood without mobilization or preselection: molecular characteristics and functional competence. PLoS One. 2010, 5(3):e9496-9504.

43. Boiron JM, Dazey B, Cailliot C, Launay B, Attal M, Mazurier F, McNiece IK, Ivanovic Z, Caraux J, Marit G, Reiffers J. Large-scale expansion and transplantation of CD34(+) hematopoietic cells: in vitro and in vivo confirmation of neutropenia abrogation related to the expansion process without impairment of the long-term engraftment capacity. Transfusion. 2006, 46(11):1934-42.

44. Escobar C, Grindem C, Neel JA, Suter SE: Hematologic changes after total body irradiation and autologous transplantation of hematopoietic peripheral blood progenitor cells in dogs with lymphoma. Vet Pathol. 2012, 49(2):341-3.

45. Warry EE, Willcox JL, Suter SE: Autologous peripheral blood hematopoietic cell transplantation in dogs with T-cell lymphoma. J Vet Intern Med. 2014, 28(2):529-37

46. Berz D, McCormack EM, Winer ES, Colvin GA, Quesenberry PJ: Cryopreservation of hematopoietic stem cells. Am J Hematol. 2007, 82(6):463-72.

47. Jeanne M, Kovacevic-Filipovic M, Szyporta M, Vlaski M, Hermitte F, Lafarge X, Duchez P, Boiron JM, Praloran V, Ivanovic Z: Low-oxygen and high-carbon-dioxide atmosphere improves the conservation of hematopoietic progenitors in hypothermia. Transfusion. 2009, 49(8):1738-46

48. Vlaski M, Negroni L, Kovacevic-Filipovic M, Guibert C, Brunet de la Grange P, Rossignol R, Chevaleyre J, Duchez P, Lafarge X, Praloran V, Schmitter JM, Ivanovic Z: Hypoxia/ hypercapnia-induced adaptation maintains functional capacity of cord blood stem and progenitor cells at $4^{\circ} \mathrm{C}$. J Cell Physiology. 2014, in press

49. Jacome-Galarza CE, Lee SK, Lorenzo JA, Aguila HL: Identification, characterization, and isolation of a common progenitor for osteoclasts, macrophages, and dendritic cells from murine bone marrow and periphery. J Bone Miner Res. 2013, 28(5):1203-13.

50. Charles JF, Hsu LY, Niemi EC, Weiss A, Aliprantis AO, Nakamura MC: Inflammatory arthritis increases mouse osteoclast precursors with myeloid suppressor function.J Clin Invest. 2012, 122(12):4592-605.

51. Nijweide PJ, Burger EH, Feyen JH: Cells of bone: proliferation, differentiation, and hormonal regulation. Physiol Rev. 1986, 66(4):855-86. 
52. Martin TJ: Historically significant events in the discovery of RANK/RANKL/OPG. World J Orthop. 2013, 4(4):186-197.

53. Muto A, Mizoguchi T, Udagawa N, Ito S, Kawahara I, Abiko Y, Arai A, Harada S, Kobayashi Y, Nakamichi Y, Penninger JM, Noguchi T, Takahashi N: Lineage-committed osteoclast precursors circulate in blood and settle down into bone. J Bone Miner Res. 2011, 26(12):2978-90.

54. Erices A, Conget P, Minguell JJ: Mesenchymal progenitor cells in human umbilical cord blood. Br J Haematol. 2000, 109(1):235-42.

55. Li P, Schwarz EM, O’Keefe RJ, Ma L, Looney RJ, Ritchlin CT, Boyce BF, Xing L: Systemic tumor necrosis factor alpha mediates an increase in peripheral CD11bhigh osteoclast precursors in tumor necrosis factor alpha-transgenic mice. Arthritis Rheum. 2004, 50(1):265-76.

56. Tjoa ST, de Vries TJ, Schoenmaker T, Kelder A, Loos BG, Everts V: Formation of osteoclast-like cells from peripheral blood of periodontitis patients occurs without supplementation of macrophage colony-stimulating factor. J Clin Periodontol. 2008, 35(7):568-75.

57. Caprioli A, Jaffredo T, Gautier R, Dubourg C, Dieterlen-Lièvre F: Blood-borne seeding by hematopoietic and endothelial precursors from the allantois. Proc Natl Acad Sci U S A. 1998, 95(4):1641-6.

58. Pardanaud L, Luton D, Prigent M, Bourcheix LM, Catala M, Dieterlen-Lievre F : Two distinct endothelial lineages in ontogeny, one of them related to hemopoiesis. Development. 1996, 122(5):1363-71.

59. Asahara T, Murohara T, Sullivan A, Silver M, van der Zee R, Li T, Witzenbichler B, Schatteman G, Isner JM: Isolation of putative progenitor endothelial cells for angiogenesis. Science. 1997, 275(5302):964-7.

60. Yoder MC: Human endothelial progenitor cells. Cold Spring Harb Perspect Med. 2012, 2(7):a006692

61. Favre J, Terborg N, Horrevoets AJ: The diverse identity of angiogenic monocytes. Eur J Clin Invest. 2013, 43(1):100-7.

62. Rehman J, Li J, Orschell CM, March KL. Peripheral blood "endothelial progenitor cells" are derived from monocyte/macrophages and secrete angiogenic growth factors. Circulation. 2003, 107(8):1164-9.

63. Liu JM, Lawrence F, Kovacevic M, Bignon J, Papadimitriou E, Lallemand JY, Katsoris P, Potier P, Fromes Y, Wdzieczak-Bakala J. The tetrapeptide AcSDKP, an inhibitor of primitive hematopoietic cell proliferation, induces angiogenesis in vitro and in vivo. Blood. 2003, 101(8):3014-20.

64. Fromes Y, Liu JM, Kovacevic M, Bignon J, Wdzieczak-Bakala J: The tetrapeptide acetylserine-aspartyl-lysine-proline improves skin flap survival and accelerates wound healing. Wound Repair Regen. 2006, 14(3):306-12.

65. Silvestre JS, Smadja DM, Lévy BI: Postischemic revascularization: from cellular and molecular mechanisms to clinical applications. Physiol Rev. 2013, 93(4):1743-802.

66. Werner N, Nickenig G: Clinical and therapeutical implications of EPC biology in atherosclerosis. J Cell Mol Med. 2006, 10(2):318-32.

67. Gössl M, Mödder UI, Gulati R, Rihal CS, Prasad A, Loeffler D, Lerman LO, Khosla $\mathrm{S}$, Lerman A: Coronary endothelial dysfunction in humans is associated with coronary retention of osteogenic endothelial progenitor cells. Eur Heart J. 2010, 31(23):2909-14. 
68. Peris P, Atkinson EJ, Gössl M, Kane TL, McCready LK, Lerman A, Khosla S, McGregor UI: Effects of bisphosphonate treatment on circulating osteogenic endothelial progenitor cells in postmenopausal women. Mayo Clin Proc. 2013, 88(1):46-55.

69. Krenning G, Zeisberg EM, Kalluri R: The origin of fibroblasts and mechanism of cardiac fibrosis. J Cell Physiol. 2010, 225(3):631-7.

70. van der Spoel TI, Jansen of Lorkeers SJ, Agostoni P, van Belle E, Gyöngyösi M, Sluijter JP, Cramer MJ, Doevendans PA, Chamuleau SA: Human relevance of pre-clinical studies in stem cell therapy: systematic review and meta-analysis of large animal models of ischaemic heart disease. Cardiovasc Res. 2011, 91(4):649-58.

71. Mitchell AJ, Sabondjian E, Blackwood KJ, Sykes J, Deans L, Feng Q, Stodilka RZ, Prato FS, Wisenberg G: Comparison of the myocardial clearance of endothelial progenitor cells injected early versus late into reperfused or sustained occlusion myocardial infarction. Int J Cardiovasc Imaging. 2013, 29(2):497-504.

72. Jantzen AE, Lane WO, Gage SM, Haseltine JM, Galinat LJ, Jamiolkowski RM, Lin FH, Truskey GA, Achneck HE: Autologous endothelial progenitor cell-seeding technology and biocompatibility testing for cardiovascular devices in large animal model. J Vis Exp. 2011, 55: e3197-3205.

73. Friedenstein, A.J.,I.I. Piatetzky-Shapiro, K.V. Petrakova: Osteogenesis in transplants of bone marrow cells. J. Embryol. Exp. Morphol. 1966, 16:381-390.

74. Friedenstein AJ, Chailakhjan RK, Lalykina KS: The development of fibroblast colonies in monolayer cultures of guinea-pig bone marrow and spleen cells. Cell Tissue Kinet. 1970, 3(4):393-403.

75. Friedenstein AJ, Chailakhyan RK, Latsinik NV, Panasyuk AF, Keiliss-Borok IV: Stromal cells responsible for transferring the microenvironment of the hemopoietic tissues. Cloning in vitro and retransplantation in vivo. Transplantation. 1974, 17(4):331-40.

76. Caplan AI: Mesenchymal stem cells. J Orthop Res. 1991, 9(5):641-50.

77. Luria EA, Panasyuk AF, Friedenstein A:. Fibroblast colony formation from monolayer cultures of blood cells. Transfusion. 1971, 11(6):345-9.

78. Fernández M, Simon V, Herrera G, Cao C, Del Favero H, Minguell JJ: Detection of stromal cells in peripheral blood progenitor cell collections from breast cancer patients. Bone Marrow Transplant. 1997, 20(4):265-71.

79. Lazarus HM, Haynesworth SE, Gerson SL, Caplan AI: Human bone marrow-derived mesenchymal (stromal) progenitor cells (MPCs) cannot be recovered from peripheral blood progenitor cell collections. J Hematother. 1997, 6(5):447-55.

80. Wexler SA, Donaldson C, Denning-Kendall P, Rice C, Bradley B, Hows JM. Adult bone marrow is a rich source of human mesenchymal 'stem' cells but umbilical cord and mobilized adult blood are not. Br J Haematol. 2003, 121(2):368-74.

81. Zvaifler NJ, Marinova-Mutafchieva L, Adams G, Edwards CJ, Moss J, Burger JA, Maini $\mathrm{RN}$ : Mesenchymal precursor cells in the blood of normal individuals. Arthritis Res. 2000, 2(6):477-88.

82. Kuznetsov SA, Mankani MH, Gronthos S, Satomura K, Bianco P, Robey PG. Circulating skeletal stem cells. J Cell Biol. 2001,153(5):1133-40.

83. Kuznetsov SA, Mankani MH, Leet AI, Ziran N, Gronthos S, Robey PG: Circulating connective tissue precursors: extreme rarity in humans and chondrogenic potential in guinea pigs. Stem Cells. 2007, 25(7):1830-9. 
84. Divya MS, Roshin GE, Divya TS, Rasheed VA, Santhoshkumar TR, Elizabeth KE, James J, Pillai RM: Umbilical cord blood-derived mesenchymal stem cells consist of a unique population of progenitors co-expressing mesenchymal stem cell and neuronal markers capable of instantaneous neuronal differentiation. Stem Cell Res Ther. 2012, 19(6):57-73.

85. Huss R, Lange C, Weissinger EM, Kolb HJ, Thalmeier K: Evidence of peripheral bloodderived, plastic-adherent CD34(-/low) hematopoietic stem cell clones with mesenchymal stem cell characteristics. Stem Cells. 2000, 18(4):252-60.

86. Han X, Liu H, Wang D, Su F, Zhang Y, Zhou W, Li S, Yang R: Alveolar bone regeneration around immediate implants using an injectable nHAC/CSH loaded with autogenic bloodacquired mesenchymal progenitor cells: an experimental study in the dog mandible. Clin Implant Dent Relat Res. 2013, 15(3):390-401.

87. Kang BJ, Ryu HH, Park SS, Koyama Y, Kikuchi M, Woo HM, Kim WH, Kweon OK: Comparing the osteogenic potential of canine mesenchymal stem cells derived from adipose tissues, bone marrow, umbilical cord blood, and Wharton's jelly for treating bone defects. J Vet Sci. 2012, 13(3):299-310.

88. Ryu HH, Kang BJ, Park SS, Kim Y, Sung GJ, Woo HM, Kim WH, Kweon OK: Comparison of mesenchymal stem cells derived from fat, bone marrow, Wharton's jelly, and umbilical cord blood for treating spinal cord injuries in dogs. J Vet Med Sci. 2012, 74(12):1617-30.

89. Lim JH, Byeon YE, Ryu HH, Jeong YH, Lee YW, Kim WH, Kang KS, Kweon OK: Transplantation of canine umbilical cord blood-derived mesenchymal stem cells in experimentally induced spinal cord injured dogs. J Vet Sci. 2007, 8(3):275-82.

90. Koerner J, Nesic D, Romero JD, Brehm W, Mainil-Varlet P, Grogan SP: Equine peripheral blood-derived progenitors in comparison to bone marrow-derived mesenchymal stem cells. Stem Cells. 2006, 24(6):1613-9.

91. Giovannini S, Brehm W, Mainil-Varlet P, Nesic D: Multilineage differentiation potential of equine blood-derived fibroblast-like cells. Differentiation. 2008, 76(2):118-29

92. Koch TG, Heerkens T, Thomsen PD, Betts DH: Isolation of mesenchymal stem cells from equine umbilical cord blood. BMC Biotechnol. 2007, 30(7):26-35.

93. Marfe G, Rotta G, De Martino L, Tafani M, Fiorito F, Di Stefano C, Polettini M, Ranalli M, Russo MA, Gambacurta A: A new clinical approach: use of blood-derived stem cells (BDSCs) for superficial digital flexor tendon injuries in horses. Life Sci. 2012, 90(2122):825-30.

94. Broeckx S, Borena BM, Zimmerman M, Mariën T, Seys B, Suls M, Duchateau L, Spaas JH: Intravenous Application of Allogenic Peripheral Blood-Derived Mesenchymal Stem Cells: a Safety Assessment in 291 Equine Recipients. Curr Stem Cell Res Ther. 2014, DOI: 10.2174/1574888X09666140220003847.

95. Ding Y, Li S, Nie G: Nanotechnological strategies for therapeutic targeting of tumor vasculature. Nanomedicine (Lond). 2013, 8(7):1209-22.

96. Fukuda K, Fujita J: Mesenchymal, but not hematopoietic, stem cells can be mobilized and differentiate into cardiomyocytes after myocardial infarction in mice. Kidney Int. 2005, 68(5):1940-3.

97. Bucala R, Spiegel LA, Chesney J, Hogan M, Cerami A: Circulating fibrocytes define a new leukocyte subpopulation that mediates tissue repair. Mol Med. 1994, 1(1):71-81.

98. Chesney J, Bacher M, Bender A, Bucala R: The peripheral blood fibrocyte is a potent antigen-presenting cell capable of priming naive T cells in situ. Proc Natl Acad Sci U S A. 1997, 94(12):6307-12. 
99. Suga H, Rennert RC, Rodrigues M, Sorkin M, Glotzbach JP, Januszyk M, Fujiwara T, Longaker MT, Gurtner GC: Tracking the elusive fibrocyte: identification and characterization of collagen-producing hematopoietic lineage cells during murine wound healing. Stem Cells. 2014, 32(5):1347-60.

100. Hartlapp I, Abe R, Saeed RW, Peng T, Voelter W, Bucala R, Metz CN: Fibrocytes induce an angiogenic phenotype in cultured endothelial cells and promote angiogenesis in vivo. FASEB J. 2001,15(12):2215-24.

101. Isgrò M, Bianchetti L, Marini MA, Bellini A, Schmidt M, Mattoli S: The C-C motif chemokine ligands CCL5, CCL11, and CCL24 induce the migration of circulating fibrocytes from patients with severe asthma. Mucosal Immunol. 2013, 6(4):718-27.

102. Scholten D, Reichart D, Paik YH, Lindert J, Bhattacharya J, Glass CK, Brenner DA, Kisseleva T: Migration of fibrocytes in fibrogenic liver injury. Am J Pathol. 2011, 179(1):189-98.

103. Mackinnon A, Forbes S: Bone marrow contributions to fibrosis. Biochim Biophys Acta. 2013, 1832(7):955-61.

104. Pilling D, Roife D, Wang M, Ronkainen SD, Crawford JR, Travis EL, Gomer RH: Reduction of bleomycin-induced pulmonary fibrosis by serum amyloid P. J Immunol. 2007, 179(6):4035-44.

105. Knežević M, Gledić D, Kukolj V, Knežević Dj, Jovanović M, Božić T, Aleksić-Kovačević $\mathrm{S}$ : Expression of $\alpha$-SMA, desmin and vimentin in canine liver with fibrosis. Acta Vet (Beograd) 2009, 59(4):361-370.

106. Aleksić-Kovačević S, Kukolj V, Kureljušić B, Marinković D, Knežević Dj, Ignjatović I, Jovanović M, Knežević M, Gledić D: Role of hepatic stellate cells (HSCs) in development of hepatic fibrosis in cats with polycystic kidney disease (PKD). Acta Vet (Beograd) 2010, 60(4):391-400.

107. Lilja-Maula L, Syrjä P, Laurila HP, Sutinen E, Rönty M, Koli K, Rajamäki MM, Myllärniemi M: Comparative Study of Transforming Growth Factor- $\beta$ Signalling and Regulatory Molecules in Human and Canine Idiopathic Pulmonary Fibrosis. J Comp Pathol. 2013, 150(4):399-407.

108. Williams KJ: Gamma herpesviruses and pulmonary fibrosis: evidence from humans, horses, and rodents. Vet Pathol. 2014, 51(2):372-84.

109. Marinković D, Kukolj V, Aleksić-Kovačević S, Jovanović M, Knežević M: The role of hepatic myofibroblasts in liver cirrhosis in fallow deer (Dama dama) naturally infected with giant liver fluke (Fascioloides magna). BMC Vet Res. 2013, 6(9):45-51.

110. Roman J, Brown KK, Olson A, Corcoran BM, Williams KJ: ATS Comparative Biology of Lung Fibrosis Working Group. An official American Thoracic Society workshop report: comparative pathobiology of fibrosing lung disorders in humans and domestic animals. Ann Am Thorac Soc. 2013, 10(6):S224-9.

111. Horňák S, Harvanová D, Ledecký V, Hluchý M, Valenčáková-Agyagosová A, Amrichová J, Rosocha J, Vaško G, Švihla R, Petrovič V. Reparation of chondral defects in rabbits by autologous and allogenous chondrocytes seeded on collagen/hyaluronan scaffold or suspended in fibrin glue. Acta veterinaria-Beograd, 64 (2014):61-72.

112. Arsenović-Ranin N, Nacka-Aleksić M, Djikić J, Perišić M, Kosec D, Pilipović I, StojićVukanić Z, Leposavić G: Thymocyte apoptosis and proliferation modeling during rat thymic involution is influenced by ovarian hormones in a thymocyte subset-specific manner. Acta veterinaria-Beograd, 2013, 63 (1): 3-21 
113. Vojvodić D, Miljanović O, Đurđević D, Gatarić S, Stanojević I, Obradović D, Šurbatović M, Francuski J: Effects of different anesthetic agents on GM-CSF, MCP1, IL1 and TNF levels in rat sepsis mode. Acta veterinaria-Beograd, 2013 63(2-3):125-136.

114. Lamagna C, Bergers $G$ : The bone marrow constitutes a reservoir of pericyte progenitors. J Leukoc Biol. 2006, 80(4):677-81.

115. Merkulova-Rainon T, Broquères-You D, Kubis N, Silvestre JS, Lévy BI: Towards the therapeutic use of vascular smooth muscle progenitor cells. Cardiovasc Res. 2012, 95(2):205-14.

116. Pignolo RJ, Kassem M: Circulating osteogenic cells: implications for injury, repair, and regeneration. J Bone Miner Res. 2011, 26(8):1685-93.

117. Kucia M, Halasa M, Wysoczynski M, Baskiewicz-Masiuk M, Moldenhawer S, ZubaSurma E, Czajka R, Wojakowski W, Machalinski B, Ratajczak MZ: Morphological and molecular characterization of novel population of CXCR4+ SSEA-4+ Oct-4+ very small embryonic-like cells purified from human cord blood: preliminary report. Leukemia. 2007, 21(2):297-303.

\title{
KRV JE BOGATA RAZLIČITIM MATIČNIM I PROGENITORSKIM ĆELIJAMA POREKLOM OD MEZODERMA
}

\author{
KOVAČEVIĆ FILIPOVIĆ Milica
}

Ispitivanja krvi i koštane srži se sistematski sprovode duže od sto godina, ali su ova tkiva i dalje izvor novih podataka od značaja za humanu i veterinarsku medicinu. Krvlju cirkulišu različite zrele ćelije kao što su eritrociti, trombociti i granulociti, ali i mali broj nediferenciranih ćelija mezodermalnog porekla: hematopoteske i mezenhimske matične ćelije i ćelije progenitori, progenitori endotelnih ćelija i jako male ćelije nalik embrionalnim. Kod odraslih organizama, koštana srž je izvor praktično svih ćelija koje se mogu naći u krvi. Mobilizacija matičnih ćelija i ćelija progenitora iz koštane srži u krv, i njihov povratak u koštanu srž ili odlazak u druga tkiva je regulisan kompleksnim procesima. Upotreba matičnih ćelija hematopoeze i ćelija progenitora u humanoj medicini, zasniva se na činjenici da mogu da se mobilišu u krv i da repopulišu koštanu srž proizvodeći zrele ćelije krvi. U ovom preglednom članku će biti opisane osnovne karakteristike matičnih ćelija i ćelija progenitora, mehanizmi mobilizacije i prelaska u tkiva. Takođe, značaj činjenice da se u krvi mogu naći različite matične ćelije i progenitorske i prekursorske ćelije je stvaljena u kontekst njihove primene u humanoj i veterinarskoj medicini. 